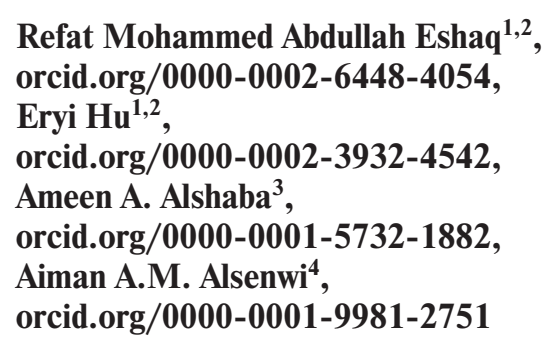

1 - School of Mechanical and Electrical Engineering, China University of Mining and Technology, Xuzhou, China, e-mail: hu@cumt.edu.cn

2 - Jiangsu Collaborative Innovation Center of Intelligent Mining Equipment, China University of Mining and Technology, Xuzhou, China

3 - College of Engineering, Minia University, Minia, Egypt

4 - College of Engineering, Arab Academy for Science, Technology \& Maritime Transport, Alexandria, Egypt

\title{
FEASIBILITY STUDY OF EXPLOITING GEARBOX OIL TEMPERATURE OF WIND TURBINE FOR IMPROVING A HEAT PUMP WATER HEATER IN COLD AREAS
}

Purpose. Feasibility of completely dispensing with solar collectors (SCs) that are used in heat pump (HP) systems for hot water in cold areas.

Methodology. Since the temperature of gearbox oil is relatively high, lots of heat can be exploited. Therefore, the recovery of this unutilized heat from gearbox oil temperature of a wind turbine shows a promising solution in improving heat pump (HP) efficiency for hot water especially in cold environment or the district that is located in the north of our planet where the solar energy is very low. This investigation focuses on the feasibility of direct conversion of mechanical energy harvested from the wind speed into thermal energy by exploiting only the friction phenomenon inside the gearbox of the wind turbine by completely dispensing with solar collectors (SCs) that are used in combined solar assisted heat pump (SAHP) because the SCs have various problems, such as large heat loss, low efficiency, freezing and tube-burst, which may limit their applications.

Findings. Results show that the wind turbine can provide the power required for HP during the winter season due to high wind speed in Xuzhou city, Jiangsu, China particularly in January. At best, coefficient of performance (COP) may reach 4.08 without $\mathrm{SCs}$, thus the suggested system ensures high COP in addition to decrease in the fuel consumption by $23.25 \%$.

Originality. Wind power driven HPs have been suggested in many pervious papers as a sustainable measure to provide heat to a house; however, to improve COP of HP system, we suggest using a wind turbine to directly drive the HP and exploit gearbox oil temperature in an assistant heat exchanger installed after the HP evaporator for providing additional thermal energy to refrigerant R12 and cooling the gearbox oil.

Practical value. The coefficient of performance (COP) of HP has reached 4.08 without SCs, so the suggested system demonstrates high COP in addition to the reduced fuel consumption. Approximately $23.25 \%$ of energy could be saved using this novel system compared to a fuel water heater for DHW.

Keywords: wind turbine, heat pump, gearbox oil temperature, water heater, thermal energy

Introduction. Over the past few decades, the risk of $\mathrm{CO}_{2}$ emissions is the toughest issue for the international community since the global warming will happen faster [1] if we still behave with-out responsibility. The $\mathrm{CO}_{2}$ emissions continually increase due to human activities such as electricity and heat production, Industry sectors and transport [2]. Based on lasts report [2], the electricity and heat production by coal are main reason for the $\mathrm{CO}_{2}$ emissions. Thus, the eco-friendly technologies of electricity and heat production has been given priority by the largest developing and developed countries. In the current century, the heat production for residential sector is a critical issue because the demand of domestic hot water (DHW) dramatically increases in cold areas especially in winter season [3-5]. Therefore, many researchers and scholars proposed technical method in order to harvest sustainable energies such as water solar collector or combined solar assisted heat pump (SAHP) which are exploited solar energy that are harvested from the sun. Furthermore, some works have been proposing wind turbine integrate with SAHP for driving the compressor of refrigeration cycle which the system can take advantage of both wind speed and solar energy simultaneously, for redaction heating and electricity demand.

There are many different methods to design SAHP [6, 7]. Tow common models are: direct expansion solar assisted heat pump (DX-SAHP), which the solar panel become the evaporator and directly expose to sun ray; and indirect system, where the solar collectors (SCs) are connected to HP by heat exchanger. Hepbasli and Kalinci [3] published survey about heat pump water systems, the reader can find more details and

(C) Refat Mohammed Abdullah Eshaq, Eryi Hu, Ameen A. Alshaba, Aiman A.M. Alsenwi, 2021 achievement in field of heating domestic water by heat pump, solar collector incorporate with heat pump (SDHWS), ground source heat pump (GSHP) as well as gas engine-driven heat pump with exploiting exhaust gas of internal combustion engine. Moreover, the reader can find numerous information about applications, modelling and modifications of SCHPs in $[8,9]$.

Yokoyama, et al. [10] investigated in $\mathrm{CO}_{2}$ heat pump with a hot water storage tank, the system composed of compressor, a gas cooler, an expansion valve and an evaporator. Luca Tagliafico, et al. [11] presented simulation study of a steady state off-design model of a water solar assisted heat pump for heating swimming pools. Chaturvedi, et al. [4] analysed long-term thermo-economic of energy conservation of direct expansion solar assisted heat pump (DX-SAHP) for low temperature water heating application. Li, et al. [12] investigated the performance of a combined solar thermal heat pump system with seasonal energy storage in order to heat space and DHW. Kong, et al. [13] designed a variable capacity DX-SAHP system for DHW. Also, the authors execute experiments for investigating the system COP, the electric power to the compressor, the evaporating and condensing pressures, and the discharge temperature of the compressor through autumn and winter conditions. In that work, the attained COP was higher than 4.0 .

Some authors discussed the shower waste water for improving COP of HP system. Chen, et al. [14] designed simulation study of a heat water heater for bathing (HPBWH), which the authors exploited the shower waste water by employing a regenerator and an evaporator for recovering the waste heat from shower water. The obtained COP of that paper was 4.97. Dond, et al. [15] presented experimental performance study of 
a novel heat pump water heater assisted with shower drain water (SDW).

In other works, the wind turbine has been suggested to drive the compressor of SAHP in order to minimize the electrical consumption be exploiting as possible the sustainable energy such as wind speed besides solar energy. Li, et al. [16] presented simulation study of dynamic performance on heat pump driven by wind turbine for heating space, the system composed of wind turbine, battery bake and HP equipment. Stanek, et al. [17] analysed an ecological heat pump system, which the system composed of electrical HP that worked based on mix of renewable and non- renewable energy. The authors utilized photovoltaic panels or wind turbines as a basic source of electricity and the electricity from grid was added as complemented balance of demand for HP. The study put forward from the ecological point of view.

Because of pipe plugging, expansion crack and tube-burst that consider the common issue for FPCs used in cold areas, which significantly affected the system reliability and sometimes even led to ineffective system [18]. Additionally, in the winter seasons, due to the relatively low ambient temperature and high relative humidity, frosting would easily take place on the surface of the solar collector (SCs) especially in the morning, which could reduce the efficiency of the collector [18]. Also, both FPCs and all-glass ETCs have numerous problems particularly in cold environment would lead to seriously limited the application [18]. To clarify, since the temperature difference between the fluid and the surrounding environment was up to $80{ }^{\circ} \mathrm{C}$ would cause great heat loss and the thermal efficiency tended to be less than $40 \%$ [18]. Taking into consideration, in the north of our planet the sun ray is very low, in some territory the sun is completely disappear or the weather becomes cloudy in most days especially on January. For above mentioned reasons, we infer that the drawbacks of SC outweigh its benefits particularly in cold environment. Therefore, this system is suggested for dispensing the SC regardless of its type.

In this paper, we propose a new method namely gearbox oil temperature of wind turbine assisted heat pump (GOTWTHP) work based on renewable and non-renewable energy to improve the HP by exploiting the generated heat of gearbox [19] of $15 \mathrm{~kW}$ vertical axis wind turban (VAWT) in order to provide additional heat to refrigeration cycle for DHW. Fig. 1 describes the cooling system of gearbox of wind turbine; the oil inside the gearbox is cooled by air, nevertheless, in this proposed method, the oil/air heat exchanger was replaced by oil/ freon heat exchanger.

As shown in Fig. 2, the VAWT directly drive the compressor [21] of HP to reduce the electric losses. Therefore, the COP would be increased compared to the HP system which utilised only "free" ambient heat.

The aim of this step is to cool the gearbox oil by refrigerant $\mathrm{R} 12$, to ensure the optimum cooling system for gearbox oil temperature and make the refrigerant reaches to superheat vapour for decreasing the power needed that required to compress the refrigerant and make sure the best performance for the compressor of HP system. Furthermore, this work studies

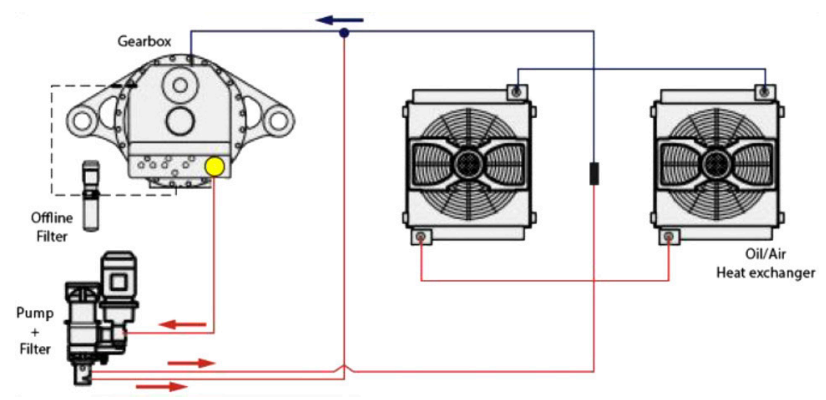

Fig. 1. Common method that is cooled the gearbox oil temperature by air (oil/air heat exchanger) [20]

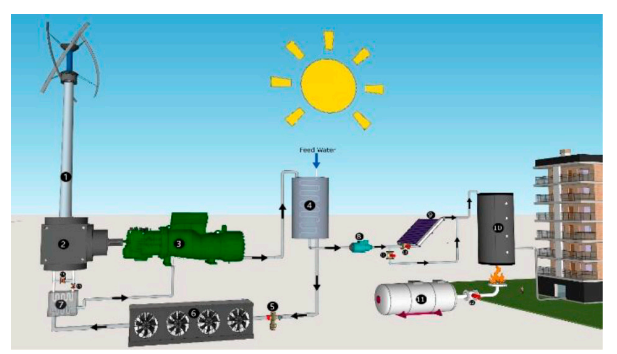

Fig. 2. The schema for the purpose of the system (GOT-WTHP) integrated with Oil/Freon Heat exchanger.

The system (GOT-WTHP) composed of 1 - Vertical axis wind turbine; 2 - Gearbox; 3 - Compressor; 4 - Condenser; 5 - Expansion valve; 6-Evaporator; 7 - Heat exchanger; 8 - Water pump; 9-Solar collector; 10-Boiler; 11 - Fuel tank; 12 - Flow control valves; and 13 - Thermostatic valves

the feasibility of heating water of residential applications at freezing point $\left(0{ }^{\circ} \mathrm{C}\right)$ in cold areas before the water enters into water heater "boiler" as shown in Fig. 2. By using this technology of GOT-WTHP, the result show that can rise water temperature of residential applications by $29^{\circ} \mathrm{C}$ depend on wind speed. Moreover, this study put forward from the point of worst case when the SCs shut down due to the reasons that we mentioned them above. Obviously, the wind speed is a basic source of thermal energy in this system and the fossil fuel was added as complemented balance of demand for DHW. The system of GOT-WTHP was designed to provide $1800 \mathrm{l} / \mathrm{hr}$ of hot water, each apartment needs $200 \mathrm{l}$ /day of hot water, consequently; the system can cover 9 apartments per hour. This study essentially builds based on experimental data, which we elaborate in detail in this paper.

Methods. Experimental data collection. The data were obtained during the winter season from 1 January to 31 January 2020. The wind speed and air temperature were measured by (WE550, Global Water, California, USA, accuracy: $4 \%$, resolution $0.5 \mathrm{~m} / \mathrm{s}),(\mathrm{T} / \mathrm{C}$ type K, Testo, Lenzkirch, Germany, accuracy: class 2 "EN 60584-2") in Xuzhou city, Jiangsu, China. The sensors were connected to the personal computer in order to save the measured values every 10 minutes as shown in Figs. 3 and 4.

Likewise, the gearbox oil temperature was measured by resistance sensor (TR099, Guilcor, Normandy, France, accuracy: class B "EN 60751", sensitivity: 100, 1000 pt), the system is adjusted to acquire data every 10 minutes of oil temperature of gearbox as shown in Fig. 5 for comparison the results of oil temperature of gearbox.

Dynamic thermal properties of the oil, gearbox efficiency and overall wind turbine performance depend on the gear-box oil temperature. It should be noted that the best performance of gearbox of VAWT when the gearbox oil temperature ranges between 40 and $45^{\circ} \mathrm{C}$. The thermal properties of oil are listed in Table 1.

System description. As presented in Fig. 6 the VAWT harvests the wind energy by converting the wind speed into mechanical energy and then transmitted it to the gearbox by shaft.

The gearbox starts to rotate and convert low speed from the shaft of wind turbine into high speed in order to directly drive the compressor, the oil temperature inside the gearbox is proportional with wind speed due to the friction between the gears as expressed in equation, $\mathrm{m} /$ day

$$
\Delta T=\frac{7800 f v D}{G\left(k_{1}+k_{2}\right)},
$$

where $\Delta T$ is the rise in temperature; $f$ is the coefficient of friction; $v$ is the sliding velocity; $D$ is the surface energy of adhesion; $G$ is the mechanical equivalent of heat; $k_{1}, k_{2}$ are heat conductivity of the two materials.

Therefore, we need to maintain the oil temperature at $40^{\circ} \mathrm{C}$ for ensuring the optimum operation of gearbox. It is noticeable 


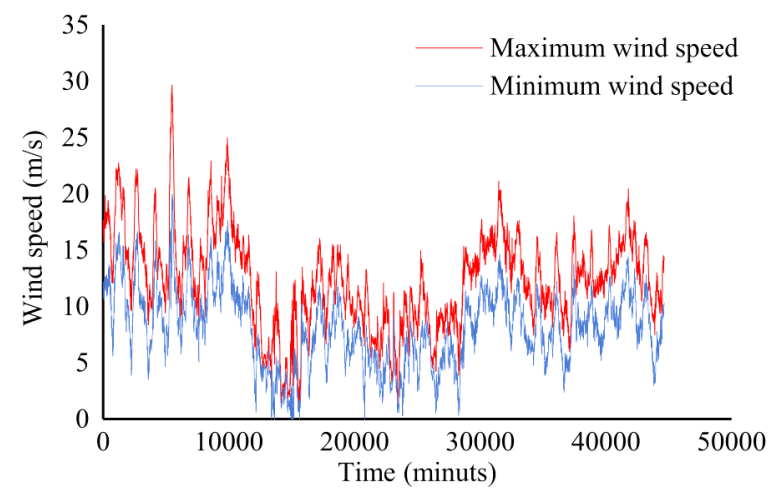

Table 1

Fig. 3. Wind speed for January

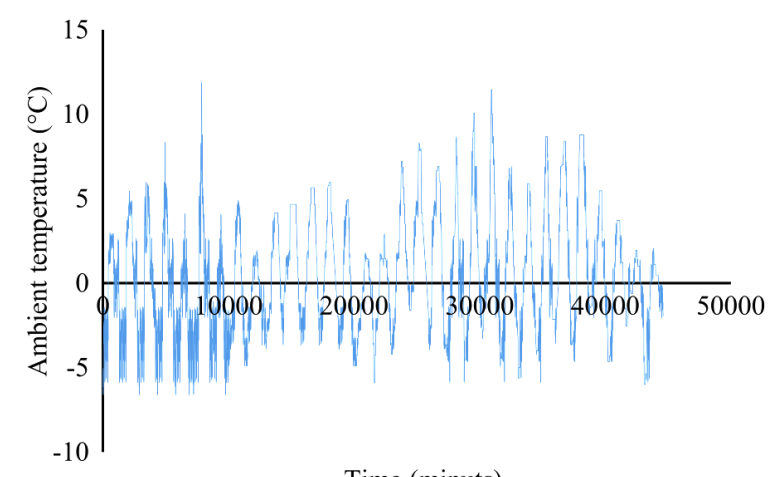

Time (minuts)

Fig. 4. Ambient air for January

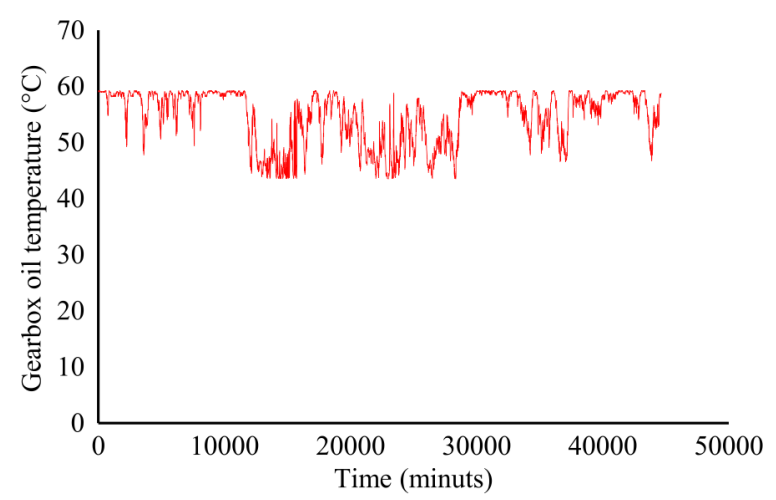

Fig. 5. Gearbox oil temperature as function in time

\begin{tabular}{|c|l|c|}
\hline Symbol & \multicolumn{1}{|c|}{ Quantity } & Value \\
\hline$\rho$ & density of refrigerants & $11.97 \mathrm{~kg} / \mathrm{m}^{3}$ \\
\hline$c_{p r}$ & $\begin{array}{l}\text { specific heat capacity of refrigerant at } \\
\text { constant pressure }\end{array}$ & $0.6155 \mathrm{~kJ} / \mathrm{kg} \cdot \mathrm{K}$ \\
\hline$c_{v r}$ & $\begin{array}{l}\text { specific heat capacity of refrigerant at } \\
\text { constant volume }\end{array}$ & $0.5175 \mathrm{~kJ} / \mathrm{kg} \cdot \mathrm{K}$ \\
\hline$h_{s a t}$ & saturation enthalpy of refrigerant & $76.27 \mathrm{~kJ} / \mathrm{kg}$ \\
\hline$V_{s}$ & suction volumetric rate of refrigerant & $0.032 \mathrm{~m}^{3} / \mathrm{s}$ \\
\hline$P_{s}$ & suction pressure & $0.2 \mathrm{MPa}$ \\
\hline$m_{\text {oil }}$ & mass flow rate of gearbox oil & $0.15506 \mathrm{~kg} / \mathrm{s}$ \\
\hline$c_{p o i l}$ & $\begin{array}{l}\text { specific heat capacity of oil at } \\
\text { constant pressure }\end{array}$ & $2.26 \mathrm{~kJ} / \mathrm{kg} \cdot \mathrm{K}$ \\
\hline$T_{\text {oin }}$ & inlet oil temperature & $40{ }^{\circ} \mathrm{C}$ \\
\hline$Q_{e v}$ & heat absorption by the evaporator & $38 \mathrm{~kW}$ \\
\hline$m_{w}$ & mass flow rate of DHW & $0.5 \mathrm{~kg} / \mathrm{s}$ \\
\hline$c_{p w}$ & $\begin{array}{l}\text { specific heat capacity of water at } \\
\text { constant pressure }\end{array}$ & $4.217 \mathrm{kj} / \mathrm{kg} \cdot \mathrm{K}$ \\
\hline$T_{w i n}$ & inlet water temperature & $0{ }^{\circ} \mathrm{C}$ \\
\hline$C . V$ & calorific value of fuel & $45.86 \mathrm{MJ} / \mathrm{kg}$ \\
\hline
\end{tabular}

in Fig. 5 the oil temperature reaches $60^{\circ} \mathrm{C}$ at rated wind speed. In this point, we can exploit the generated heat in gearbox by using the heat ex-changer to heat up the refrigerant and reduce the oil temperature to $40{ }^{\circ} \mathrm{C}$. This step can ensure that the refrigerant lie in superheat region before enter to the compressor.

The temperature sensors work as follows:

- if the temperature is less than $\sim 40{ }^{\circ} \mathrm{C}$ the thermostatic valve 2 is completely closed and thermostatic valve 1 is opened; - if temperature reaches $40{ }^{\circ} \mathrm{C}$ the thermostatic valve 2 is partially opened and heat exchanger start working;

- the thermo-static valve 2 will gradually open depend on the gearbox oil temperature;

- thermostatic valve 1 is proposed in order to ensure the oil temperature that inlet into the gearbox does not exceed $40{ }^{\circ} \mathrm{C}$;

- the thermostatic valve 2 will turn off when the temperature that outlet from the gearbox becomes less than $40^{\circ} \mathrm{C}$.

The compressor raise pressure of vapor refrigerant (isentropic compression) depend on the power that came from the

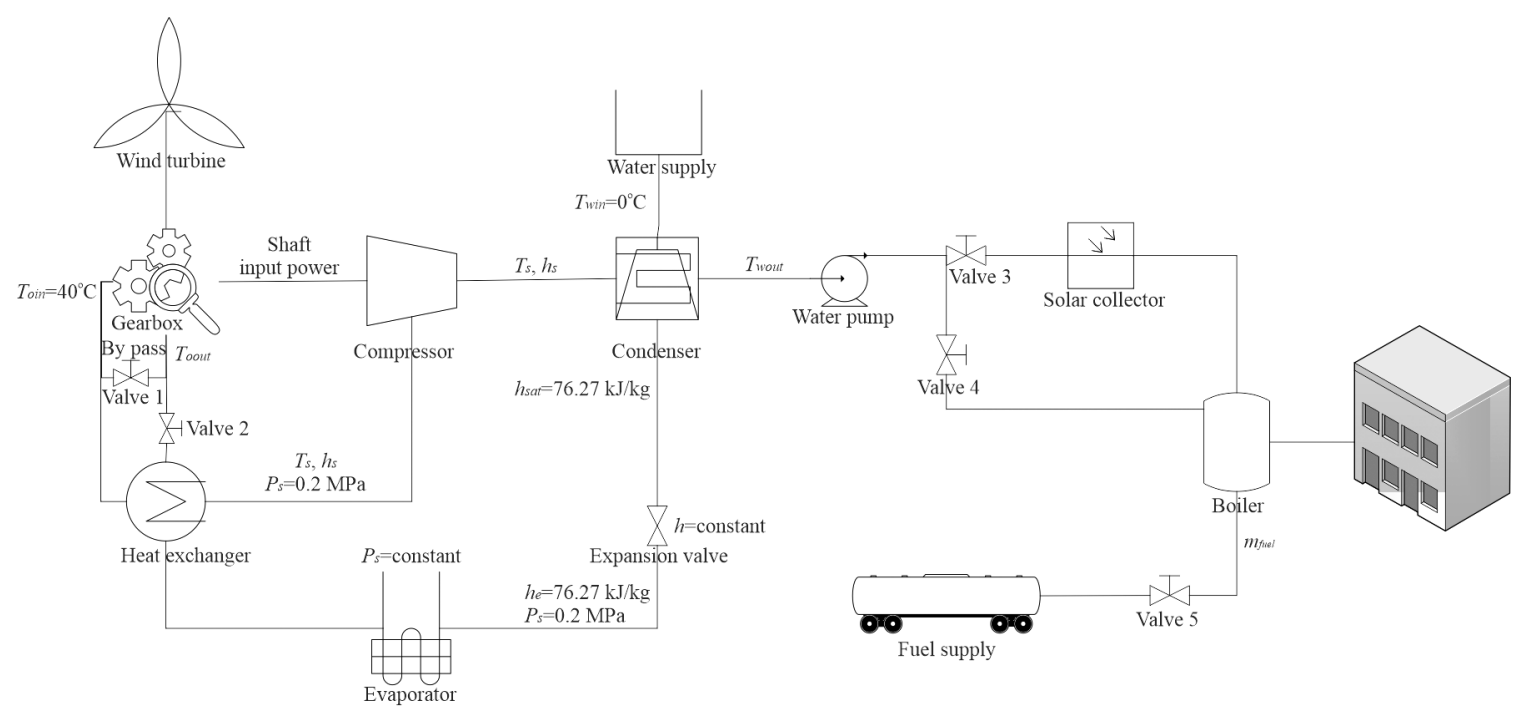

Fig. 6. Schema for the suggested system (GOT-WTHP) 
wind turbine which essentially rely on wind speed. Subsequently, the vapor of refrigerant goes to condenser for heating the water supply and condensation (Constant pressure heat rejection). Thereafter, the expansion valve reduces the pressure to $P_{s}=0.2 \mathrm{MPa}, T=-15^{\circ} \mathrm{C}$ (adiabatic expansion); afterwards, the refrigerant pass through the evaporator to gain thermal energy from the surrounding air (constant pressure heat absorption). It should be noted that the minimum ambient temperature in Xuzhou city did not exceed $-6.61{ }^{\circ} \mathrm{C}\left(T_{\text {air }}>\right.$ $>-6.61{ }^{\circ} \mathrm{C}$ ) on January. To clarify, the surrounding air is warmer than the refrigerant after expansion process. Consequently, we can avail the ambient temperature as heat source as possible for providing latent heat for refrigerant. Taking into consideration that the valve 3 will be closed because the solar energy is low, also this proposed method works under the assumption that the sun is completely disappear. Thus, we can dispense the solar collector (SC) in order to decrease the heat losses that take place through it. Finally, the warm water that came from the condenser will pass from valve 4 throughout insulated pipe to the boiler. The technical specifications of wind turbine are presented in Table 2.

The average wind speed was determined by using equation in order to estimate the power $E\left(u_{\infty}\right)$ based on the curve power of VAWT

$$
u_{\infty}=\frac{u_{\max }+u_{\min }}{2},
$$

where, $u_{\max }, u_{\min }$ are the maximum and minimum wind speed as illustrated in Fig. 3. Then, the pressure ratio was calculated by equation

$$
r_{p}=\left(\frac{E\left(u_{\infty}\right)}{\frac{\gamma}{\gamma-1} P_{s} V_{s}}+1\right)^{\frac{y}{y-1}} .
$$

Whence

$$
\begin{gathered}
r_{p}=\frac{P_{d}}{P_{s}} ; \\
y=\frac{c_{p r}}{c_{v r}} ; \\
V_{s}=\frac{\dot{m}_{r}}{\rho} ; \\
\dot{m}_{r}=\frac{\dot{m}_{w} c_{p w}\left(T_{\text {wout }}-T_{\text {win }}\right)}{\left(h_{d}-h_{\text {sat }}\right)},
\end{gathered}
$$

Table 2

Technical specifications of wind turbine

\begin{tabular}{|l|c|}
\hline \multicolumn{1}{|c|}{ Specifications } & Value \\
\hline Rated power & $15 \mathrm{~kW}$ \\
\hline Rated wind speed & $12 \mathrm{~m} / \mathrm{s}$ \\
\hline Cut-in wind speed & 3 to $4 \mathrm{~m} / \mathrm{s}$ \\
\hline Cut-out wind speed & 28 to $32 \mathrm{~m} / \mathrm{s}$ \\
\hline Rotor diameter & $7.25 \mathrm{~m}$ \\
\hline Rotor height & $6.5 \mathrm{~m}$ \\
\hline Swept area & $51.5 \mathrm{~m}^{2}$ \\
\hline Number of blades & 3 \\
\hline Gearbox type & spur/2 stags \\
\hline Gearbox oil type & polyalphaolefin (PAO) \\
\hline Brake system & Yes/inside the gearbox \\
\hline
\end{tabular}

where $E\left(u_{\infty}\right)$ is the power input which estimated from the power curve; $P_{d}, P_{s}, V_{s}$ are the discharge pressure, suction pressure and volume flow rate, respectively; $\gamma$ is the isentropic index; $\dot{m}_{r}, \rho$ are the mass flow rate and density of refrigerant R12; $T_{\text {wout }}, T_{\text {win }}$ are the water temperature that are left and interred the condenser; $\dot{m}_{w}$ is the mass flow rate of water; $c_{p w}$ is the specific heat capacity of water at constant pressure; $h_{d}, h_{\text {sat }}$ are the discharge and saturation enthalpy.

Because of the change in specific heat capacity values of the refrigerant at constantan pressure and volume $c_{p r}, c_{v r}$ are small, we assumed that the isentropic index $\gamma$ is constant. Then the heat absorption from the evaporator $Q_{e v}$ and heat exchanger $Q_{o i l}$ were determined as follows

$$
\begin{gathered}
Q_{\text {oil }}=\dot{m}_{\text {oil }} c_{\text {poil }}\left(T_{\text {oout }}\left(u_{\infty}\right)-T_{\text {oin }}\right) ; \\
Q_{e v}=\dot{m}_{r}\left(h_{s}-h_{\text {sat }}\right),
\end{gathered}
$$

where $\dot{m}_{\text {oil }}, c_{\text {poil }}$ are the mass flow rate and specific heat capacity of oil, respectively; $T_{\text {oout }}\left(u_{\infty}\right), T_{\text {oin }}$ are the oil temperature that are left and interred the gearbox of VAWT, respectively.

The total heat absorption $Q_{a d d}$ and compressor work $W_{\text {comp }}$ of the HP system can be expressed as

$$
\begin{aligned}
Q_{a d d} & =Q_{o i l}+Q_{e v} ; \\
W_{\text {comp }} & =m_{r}\left(h_{d}-h_{s}\right) .
\end{aligned}
$$

Keep in mind that the coefficient of performance $C O P$ is proportional with total heat absorption $Q_{a d d}$, consequently, when total heat absorption increase, the $C O P$ rise. The fundamental reason that make increasing in $C O P$ is to utilize the temperature of the gearbox oil as extra heat source besides "free" ambient heat which represent the evaporator

$$
C O P=\frac{Q_{a d d}}{W_{c o m p}} .
$$

Once we calculated the total heat absorption that harvested from "free" ambient temperature "evaporator" and oil of the gearbox "heat exchanger" which was generated by the friction between gears as a function in wind speed as demonstrated in Figs. 2 and 5, the enthalpy of suction point $h_{s}$ was determined at constant pressure $(0.2 \mathrm{MPa})$ as

$$
h_{s}=\frac{Q_{a d d}}{\dot{m}_{r}}+h_{\text {sat }} .
$$

The thermal property of refrigerant R12 such as temperature $T_{s}$, quality $x$ and entropy $S_{s}$ were calculated by using engineering equation solver (EES) at pressure constant (0.02 MPa). Afterwards, we determined the discharge enthalpy and temperature at isentropic process ( $s=$ constant). Subsequently, the temperature of DHW and mass flow rate were estimated as follow

$$
\begin{gathered}
T_{\text {wout }}=\frac{\dot{m}_{r}\left(h_{d}(t)-h_{\text {sat }}\right)}{\dot{m}_{w} c_{p w}}+T_{\text {win }} ; \\
\dot{m}_{f}=\frac{\dot{m}_{w} c_{p w}\left(T_{\text {wout }}(t)-T_{\text {win }}\right)}{C . V} .
\end{gathered}
$$

Note that, the temperature of DHW $T_{\text {wout }}$ and mass flow rate of fuel consumption $\dot{m}_{f}$ are function in average wind speed that were measured every 10 minutes by wind speed sensor. To start the simulation, the assumptions of thermal properties are listed in Table 1.

Results and discussion. The pursuer ratio of compressor that harvested from the wind speed during January is illustrated in Fig. 7. As we mentioned in section 1 the need of hot water increases along the drop of the ambient temperature. Because January has the lowest monthly average ambient temperature, it has the highest heat production demand. The maximum pres- 
sure ratio reach (7.38) at rated speed of wind turbine. The fluctuation of the pressure is noticeable due to the natural of wind speed is unstable with time as shown in Fig. 3, therefore, the on/ off control should be incorporated when the wind speed does not satisfy the power needed. Fig. 8 displays the relationship between pressure ratio and wind speed. We can notice the maximum pressure ratio are obtained at rated wind speed $(12 \mathrm{~m} / \mathrm{s})$.

Fig. 9 demonstrates the performance of heat exchanger as function in time on January. It should be noted that the Fig. 9 refers the heat obtained from the gearbox oil temperature based on experimental results. The correlations between the oil temperature and wind speed are shown in Fig. 10. The maximum benefits take place when the wind speed reach $12 \mathrm{~m} / \mathrm{s}$. The oil temperature in gearbox is proportional with wind speed also identical with curve power of wind speed. As we mentioned in section above, the heat generated in gearbox depend on type of oil, gearbox, material of gear as well as wind speed. If we substitute the results in Fig. 9 in equation 10, the results of total heat absorption by heat exchanger and evaporator are presented in Fig. 11 at steady state case with respect the heat absorption by evaporator is constant ( $38 \mathrm{~kW})$. This assumption is logical because the control system of evaporator work as follows:

- if the ambient temperature is low the fan speed of evaporator will be high to provide sufficient mass flow rate;

- when the ambient temperature starts to increase with time the fan speed of evaporator decreases depend on ambient temperature.

In realistic working conditions, the system should be shut down when the wind speed is low. Fig. 12 illustrates the change in heat absorption with time on January. It is notice-able, the heat absorption above $38 \mathrm{~kW}$ that mean the refrigerant R12 at suction pressure $P_{s}=0.2 \mathrm{MPa}$ leave superheated vapor from the heat exchanger. Taking into consideration when the heat absorption equal zero at specific time in Fig. 12, the operation of GOT-WTHP is stopped, since the wind speed is insufficient to accomplish the process.

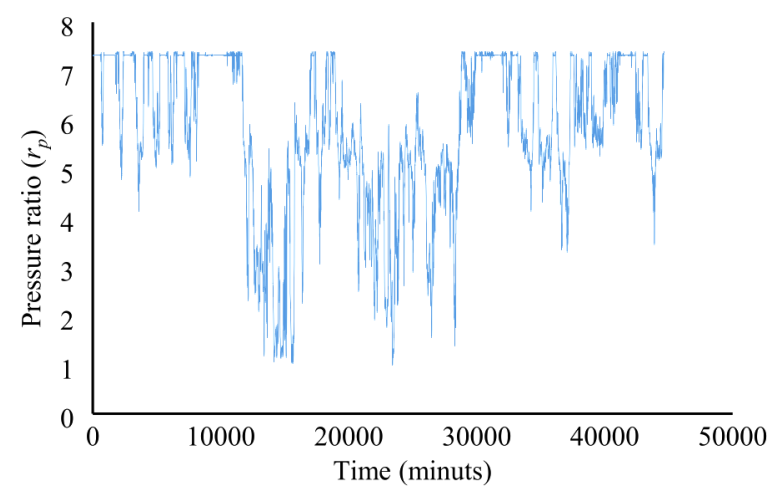

Fig. 7. Variation of pressure ratio $\left(r_{p}\right)$ every 10 minutes during January

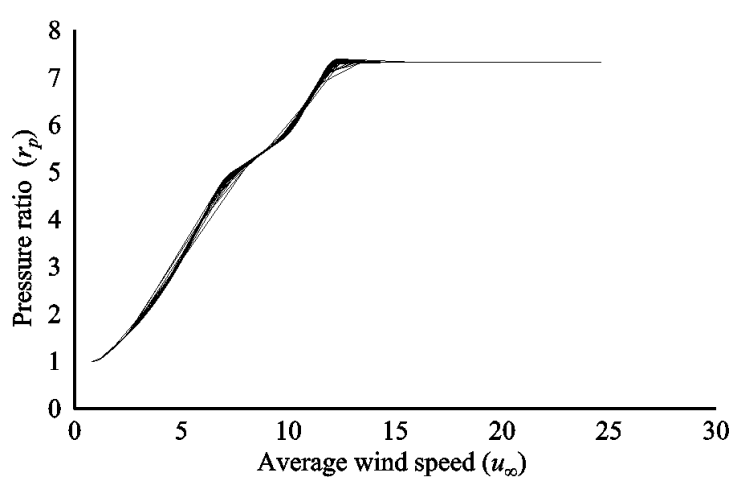

Fig. 8. Variation of pressure ratio ( $r p$ ) as function in average wind speed on January

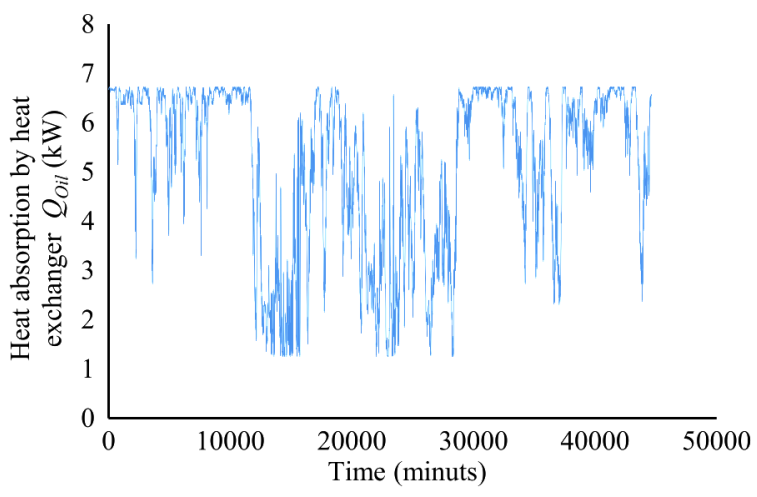

Fig. 9. Heat absorption by heat exchanger

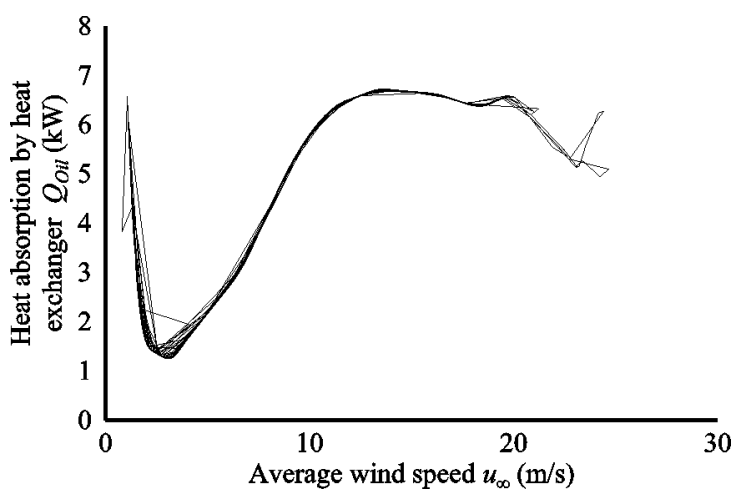

Fig. 10. Heat absorption by heat exchanger as function in average wind speed

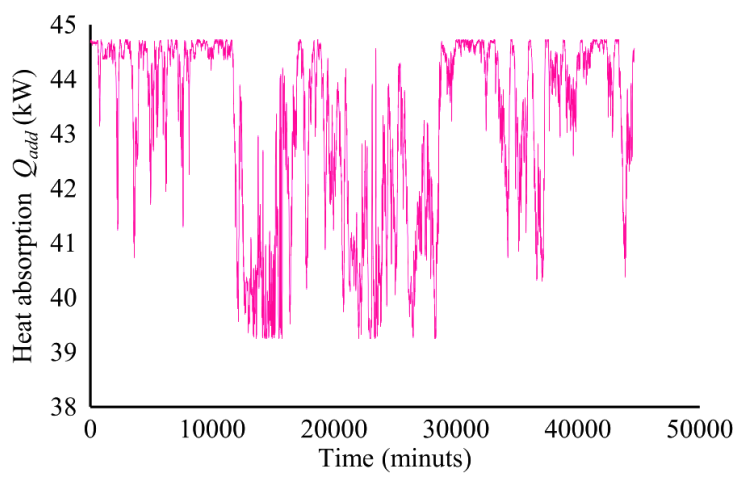

Fig. 11. Heat absorption by heat exchanger and evaporator

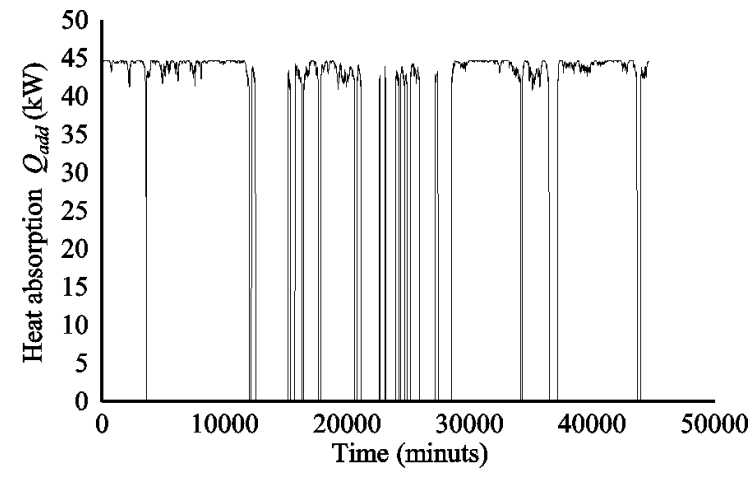

Fig. 12. Heat collected by heat exchanger and evaporator at working hours ("working hours" means when the wind speed is suitable to provide sufficient thermal and mechanical energy for refrigeration cycle) 
It should be noted that the evaporator designed to ensure the refrigerant leaving the evaporator at saturation vapor; thereafter goes to the heat exchanger for cooling the oil of gearbox in order to enter to the compressor at superheated vapor. Fig. 13 demonstrates the behaver of the enthalpy and temperature of refrigerant with time at suction point of compressor. Also, Figs. 14, 15 show the entropy and quality of refrigerant vapor with time at suction point of compressor.

As it can be seen in Fig. 15 the quality of refrigerant is $100 \%$ before compressed process; consequently, the main condition of compressed process is satisfied which state that the refrigerant must be superheated vapor before enter the compressor. Having compressed the refrigerant for raising the pressure, the temperature and enthalpy of refrigerant vapor were increased depend on wind speed that the wind turbine harvested as displayed in Fig. 16, the red line refers the discharge temperature which is varied from 45.4 to $85.85^{\circ} \mathrm{C}$ and blue line represents the discharge enthalpy that ranged between 209 and $231.90 \mathrm{~kJ} / \mathrm{kg}$ throughout January. The performance of HP systems, namely $C O P$ values, varied from 2.99 to

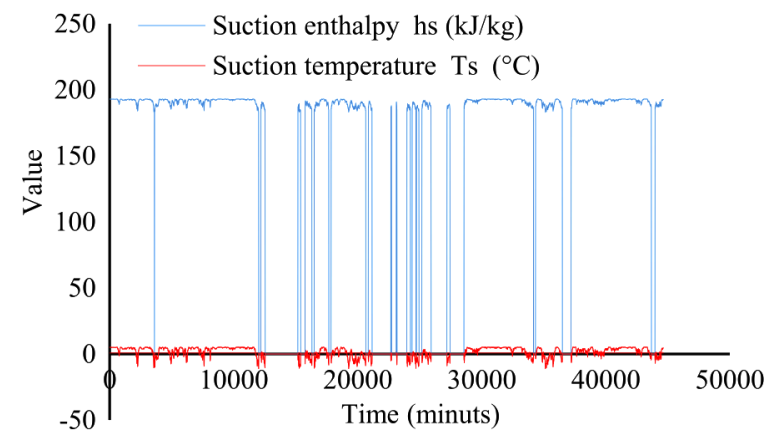

Fig. 13. The enthalpy and temperature of refrigerant $R 12$ at suction point of the compressor

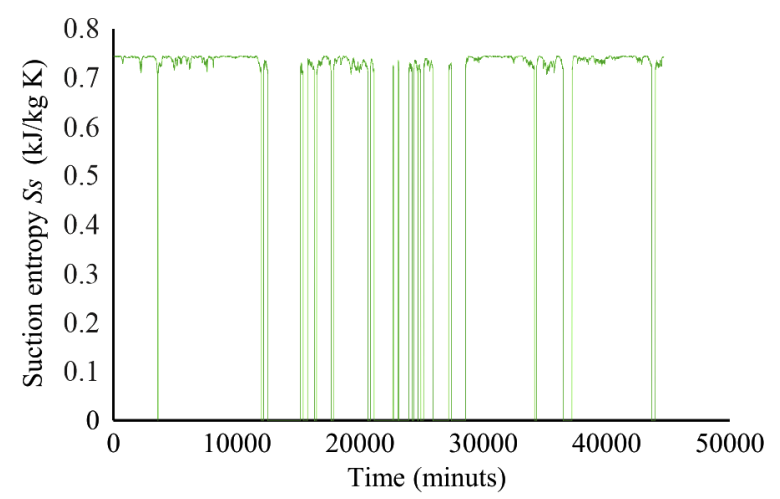

Fig. 14. The entropy of refrigerant $R 12$ at suction point of the compressor

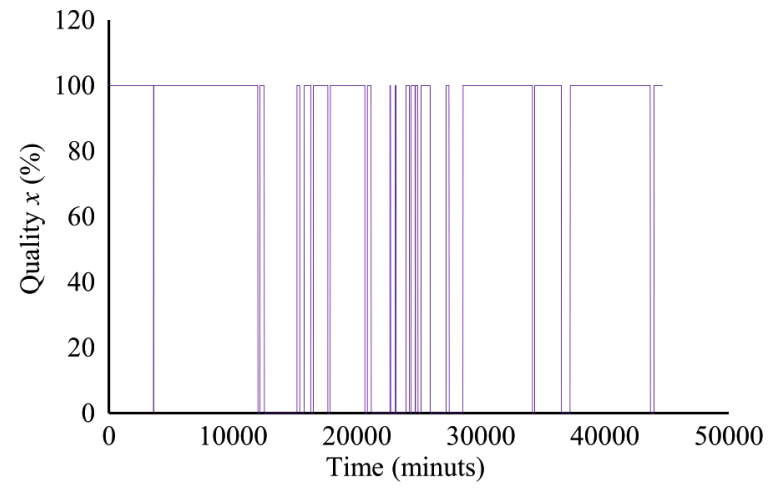

Fig. 15. The quality of refrigerant R12 at suction point of the compressor
4.08, as shown in Fig. 17, while good $C O P$ was obtained when the wind speed above rated speed $(12 \mathrm{~m} / \mathrm{s})$. It is noticeable that the $C O P$ is abusively fluctuated owing to wind speed fluctuation as well as ambient temperature.

After the refrigerant vapor leaving the compressor with high pressure and temperature, all the latent and sensible heat will be transferred into the water as presented in Fig. 18. Note that the temperature of water is zero when the process was shouted down and start to increase between 24 and $29{ }^{\circ} \mathrm{C}$ at working hours.

Now, the purpose of this proposed system to minimize the fuel consumption in boiler as illustrated in Fig. 19. As shown in Fig. 18 the domestic water inters to the condenser at $0{ }^{\circ} \mathrm{C}$ and then rise its temperature based on wind speed besides ambient temperature. In other word, When the domestic water temperature increases the fuel consumption needed to heat up the water decrease. Note that, the red line represents the mass flow rate of fuel without system of GOT-WTHP whereas black line refers to the mass flow rate of fuel when GOT-WTHP con-

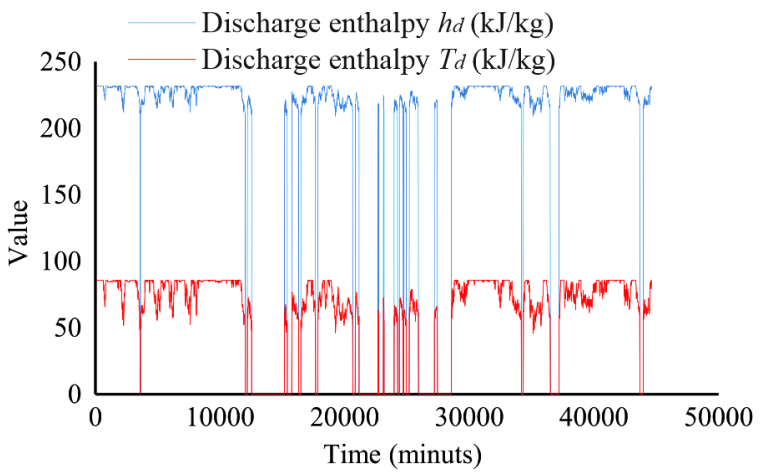

Fig. 16. The enthalpy and temperature of refrigerant $R 12$ at discharge point of the compressor

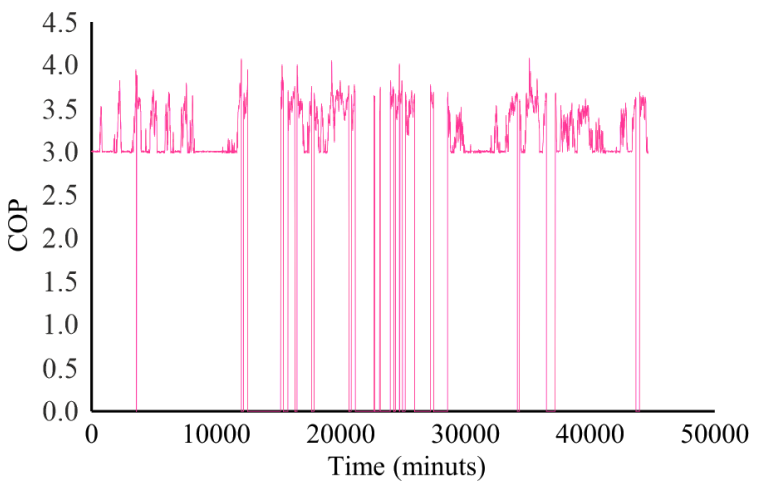

Fig. 17. Coefficient of performance (COP) of HP system every 10 minutes during January

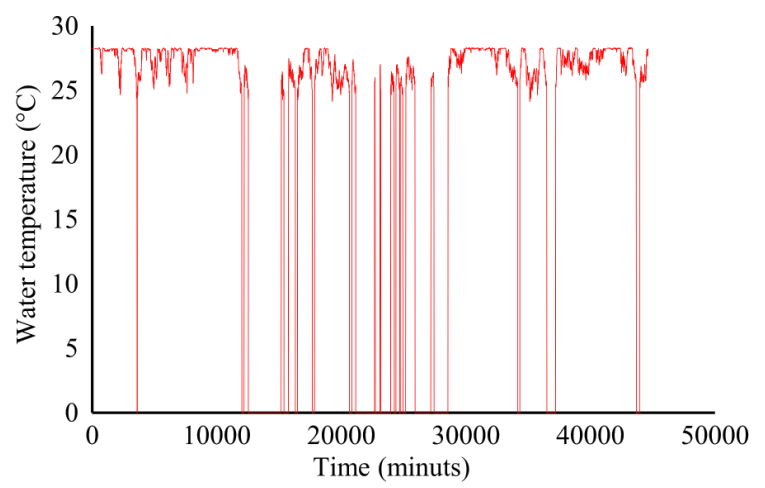

Fig. 18. Water temperatures which leave from the condenser of refrigeration cycle toward the boiler 


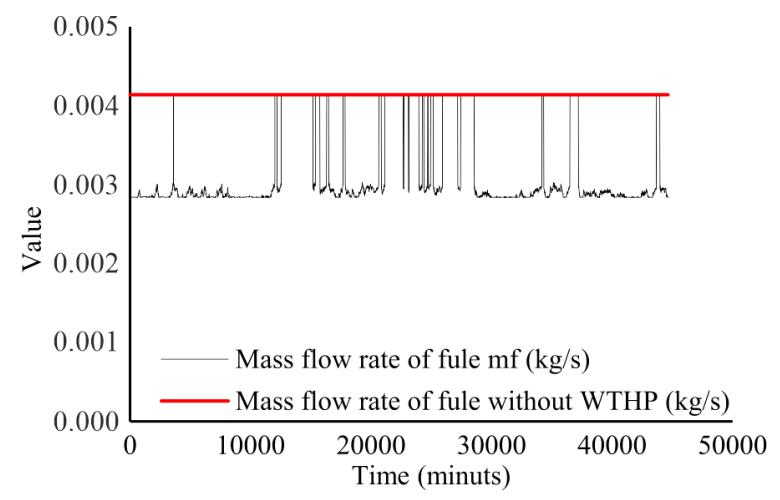

Fig. 19. Comparison between mass flow rate of fuel consumption with and without GOT-WTHP

nected with boiler. It should be noted that the mass flow rate of fuel reduces from 0.0041 to $0.0028 \mathrm{~kg} / \mathrm{s}$ at working hours of GOT-WTHP thereafter suddenly climbed to 0.0041 when the GOT-WTHP system shut down as explained that whey we must make the system stopped on work.

As demonstrated in Table 3, we can observe that the fuel consumption is remarkable reduced, consequently, the money of running cost also decreased. It can be obviously observed that the reduction of mass flow rate of fuel consumption is 8.50548 ton/month for GOT-WTHP, whereas the fuel consumption without GOT-WTHP is 11.08302 ton/month. If we assume the price of ton of fuel that needed for DHW is $450 \$ /$ ton, it is noticeable that the running cost of GOT-WTHP decreased to 3827.466 \$/month compared to 4987.359 \$/month when the system work without GOT-WTHP. The total saving money per month is $1159.893 \$ /$ month. Although the wind speed is unstable in certain hours, this proposed system of GOT-WTHP which exploited the generated heat inside the gearbox of wind turbine successfully reduce the fuel consumption needed to heat up DHW by $23.25 \%$ and this percentage fluctuate depend on wind speed as well as ambient temperature with dispensing on SC. According to the result that were presented in Figs. 18, 19 and Table 3 based on experimental data collection as well as steady state simulation, there is no doubt that the proposed system successful address the problem that we mentioned in an introduction section. We should consider not only the wind speed influence on the performance of system but the type of refrigerant and gearbox oil also effects on it.

Conclusions. A method utilizing a VAWT and its gearbox for DHW was presented in this paper. The gearbox oil temperature also played an important role; it is also a fundamental part of this investigation. We exploited the heat generated in gear-box in order to heat the refrigerant with respect the performance of the gearbox. The purpose of this step is to obtain high quality of vapor refrigerant "superheat vapor" before compression process to ensure best performance for compressor and refrigeration cycle.

This proposed method not only can be applied in could area that sun is disappeared in most days especially in winter

Table 3

Compression between water boiler with and without GOT-WTHP

\begin{tabular}{|l|c|c|c|}
\hline \multicolumn{1}{|c|}{ System } & $\begin{array}{c}\text { Fuel } \\
\text { consumption } \\
\text { ton/month }\end{array}$ & $\begin{array}{c}\text { Running } \\
\text { cost } \\
\$ / \text { month }\end{array}$ & $\begin{array}{c}\text { Saving } \\
\text { money } \\
\$ / \text { month }\end{array}$ \\
\hline $\begin{array}{l}\text { Water boiler Without } \\
\text { GOT-WTHP }\end{array}$ & 11.08302 & 4987.359 & - \\
\hline $\begin{array}{l}\text { GOT-WTHP incorporate } \\
\text { with water boiler }\end{array}$ & 8.50548 & 3827.466 & 1159.893 \\
\hline
\end{tabular}

seasons but also can work in evening time with completely dispensing on solar collector (SC). Overall, this work is reliable, particularly in DHW. Furthermore, this technology is useful and effective owing to its ability to address the problems of shortage in solar energy and successfully reducing the fuel consumption to heat water for residential uses. Therefore, the $\mathrm{CO}_{2}$ emissions will certainly redact.

Wind power to the compressor, pressures ratio, thermal energy of gearbox oil, suction enthalpy and temperature, quality of refrigerant vapor, discharge enthalpy and temperature of the compressor as well as COP during January were investigated in this unprecedented work in order to be helpful for further investigations of the system control and application.

Acknowledgements. This work is financially supported by the National Natural Science Foundation of China (Grant No. 51875568), the National Key Research and Development Program of China (Grant No. 2018YFC0604503), the Priority Academic Program Development of Jiangsu Higher Education Institutions (PAPD) and the Top-Notch Academic Programs Project of Jiangsu Higher Education Institutions. Refat M.A. Eshaq thanks China University of Mining and Technology (CUMT) and China Scholarship Council (CSC) for giving him the chance to continue his postgraduate studies; also, deeply thanks his supervisor, Prof. Eryi Hu for his interest and expert guidance.

\section{References.}

1. Xu, Y., Ramanathan, V., \& Victor, D. G. (2018). Global warming will happen faster than we think. Nature, 564(7734), 30-32.

2. Peters, G.P., Andrew, R.M., Canadell, J.G., Friedlingstein, P., Jackson, R. B., Korsbakken, J.I., \& Peregon, A. (2019). Carbon dioxide emissions continue to grow amidst slowly emerging climate policies. Nature Climate Change, 10(1), 3-6. https://doi.org/10.1038/s41558-019-0659-6.

3. Hepbasli, A., \& Kalinci, Y. (2009). A review of heat pump water heating systems. Renewable and Sustainable Energy Reviews, 13(6-7), 1211-1229. https://doi.org/10.1016/j. rser.2008.08.002.

4. Chaturvedi, S. K., Gagrani, V.D., \& Abdel-Salam, T. M. (2014). Solar-assisted heat pump - A sustainable system for low-temperature water heating applications. Energy Conversion and Management, 77, 550-557. https://doi.org/10.1016/j. enconman.2013.09.050.

5. Poppi, S., Sommerfeldt, N., Bales, C., Madani, H., \& Lundqvist, P. (2018). Techno-economic review of solar heat pump systems for residential heating applications. Renewable and Sustainable Energy Reviews, 81, 22-32. https://doi. org/10.1016/j.rser.2017.07.041.

6. Banister, C. J., \& Collins, M. R. (2015). Development and performance of a dual tank solar-assisted heat pump system. Applied Energy, 149, 125-132. https://doi.org/10.1016/j.apenergy.2015.03.130

7. Sterling, S. J., \& Collins, M. R. (2012). Feasibility analysis of an indirect heat pump assisted solar domestic hot water system. Applied Energy, 93, 11-17. https://doi.org/10.1016/j. apenergy.2011.05.050.

8. Mohanraj, M., Belyayev, Y., Jayaraj, S., \& Kaltayev, A. (2018). Research and developments on solar assisted compression heat pump systems - A comprehensive review (Part A: Modeling and modifications). Renewable and Sustainable Energy Reviews, 83, 90-123. https://doi.org/10.1016/j.rser.2017.08.022.

9. Myrzakhmetov, B., Sultabayev, A., \& Toktamissova, S. (2020). Substantiation of the methodology for modeling and calculating the optimal operating modes of a tandem pumping installation when mining uranium. Mining of Mineral Deposits, 14(4), 59-65. https://doi.org/10.33271/mining14.04.059.

10. Yokoyama, R., Wakui, T., Kamakari, J., \& Takemura, K. (2010). Performance analysis of a $\mathrm{CO}_{2}$ heat pump water heating system under a daily change in a standardized demand. Energy, 35(2), 718-728. https://doi.org/10.1016/j.energy.2009.11.008. 
11. Tagliafico, L.A., Scarpa, F., Tagliafico, G., \& Valsuani, F. (2012). An approach to energy saving assessment of solar assisted heat pumps for swimming pool water heating. Energy and Buildings, 55, 833-840. https://doi.org/10.1016/j.enbuild.2012.10.009. 12. Li, H., Sun, L., \& Zhang, Y. (2014). Performance investigation of a combined solar thermal heat pump heating system. Applied Thermal Engineering, 71(1), 460-468. https://doi. org/10.1016/j.applthermaleng.2014.07.012.

13. Kong, X., Sun, P., Li, Y., Jiang, K., \& Dong, S. (2018). Experimental studies of a variable capacity direct-expansion solar-assisted heat pump water heater in autumn and winter conditions. Solar Energy, 170, 352-357. https://doi. org/10.1016/i.solener.2018.05.081.

14. Chen, W., Liang, S., Guo, Y., Cheng, K., Gui, X., \& Tang, D. (2013). Investigation on the thermal performance and optimization of a heat pump water heater assisted by shower waste water. Energy and Buildings, 64, 172-181. https:// doi.org/10.1016/i.enbuild.2013.04.021.

15. Dong, J., Zhang, Z., Yao, Y., Jiang, Y., \& Lei, B. (2015). Experimental performance evaluation of a novel heat pump water heater assisted with shower drain water. Applied Energy, 154, 842-850. https://doi.org/10.1016/j.apenergy.2015.05.044. 16. Li, H., Campana, P. E., Tan, Y., \& Yan, J. (2018). Feasibility study about using a stand-alone wind power driven heat pump for space heating. Applied Energy, 228, 1486-1498. https://doi.org/10.1016/j.apenergy.2018.06.146.

17. Stanek, W., Simla, T., \& Gazda, W. (2019). Exergetic and thermo-ecological assessment of heat pump supported by electricity from renewable sources. Renewable Energy, 131, 404-412. https://doi.org/10.1016/j.renene.2018.07.084.

18. Zou, B., Dong, J., Yao, Y., \& Jiang, Y. (2016). An experimental investigation on a small-sized parabolic trough solar collector for water heating in cold areas. Applied Energy, 163, 396-407. https://doi.org/10.1016/j.apenergy.2015.10.186.

19. Li, W., Zhai, P., Tian, J., \& Luo, B. (2018). Thermal analysis of helical gear transmission system considering machining and installation error. International Journal of Mechanical Sciences, 149, 1-17.https://doi.org/10.1016/j.ijmecsci.2018.09.036. 20. Sequeira, C., Pacheco, A., Galego, P., \& Gorbeña, E. (2019). Analysis of the efficiency of wind turbine gearboxes using the temperature variable. Renewable Energy, 135, 465-472. https://doi.org/10.1016/i.renene.2018.12.040.

21. Li, S., \& Dai, Y. (2015). Design and Simulation Analysis of a Small-Scale Compressed Air Energy Storage System Directly Driven by Vertical Axis Wind Turbine for Isolated Areas. Journal of Energy Engineering, 141(4), 04014032. https://doi.org/10.1061/ (asce)ey.1943-7897.0000207.

\section{Техніко-економічне обгрунтування використання редукторних мастил вітрової турбіни для поліпшення роботи теплових насосів у холодному кліматі}

$$
\begin{gathered}
\text { P. М. А. Ешак } \\
\text { А.А. А. М. Алсенві }{ }^{4}
\end{gathered}
$$

1 - Факультет машинобудування та електроінженерії, Китайський університет гірничої справи та технологій, м. Сюйчжоу, Китай (Китайська Народна Республіка), e-mail: hu@cumt.edu.cn

2 - Цзянсуський об’єднаний інноваційний центр інтелектуального обладнання, Китайський університет гірничої справи та технологій, м. Сюйчжоу, Китай (Китайська Народна Республіка)

3 - Інженерний коледж, Університет Мінії, м. Мінья, Єгипет (Арабська Республіка Єгипет)

4 - Інженерний коледж, Арабська академія науки, технології та морського транспорту, м. Олександрія, Єгипет (Арабська Республіка Єгипет)
Мета. Техніко-економічне обгрунтування (ТЕО) повної відмови від сонячних колекторів (СК), що використовуються в системах з тепловими насосами (ТН) для забезпечення теплопостачання в холодних районах.

Методика. Оскільки температура редукторних мастил відносно висока, значну кількість тепла можна використовувати. Утилізація невикористаного тепла редукторних мастил вітрової турбіни стає перспективним рішенням проблеми підвищення ефективності роботи теплонасосів для теплопостачання, особливо в холодному кліматі або в районах, що розташовані в північних широтах, де частка надходження сонячної енергії невисока. Дане дослідження стосується ТЕО прямого перетворення механічної енергії вітру в теплову за рахунок тертя всередині редуктора вітрової турбіни з повним виключенням використання сонячних колекторів, що застосовуються в комбінованих сонячних теплонасосах і мають ряд недоліків - великі тепловтрати, низька ефективність, замерзання та прорив труб - що звужує сферу їх застосування.

Результати. Дослідження показало, що вітрова турбіна може забезпечити енергію, яка необхідна для теплового насоса взимку (особливо в січні) завдяки високій швидкості вітру в окрузі Сюйчжоу, провінції Цзянсу, Китай. Навіть без використання сонячних колекторів коефіцієнт корисної дії (ККД) пропонованої системи може досягати 4,08 при зменшенні споживання палива на $23,25 \%$.

Наукова новизна. У попередніх дослідженнях пропонувалося використання вітрової турбіни для приведення в дію теплонасоса, що надійно забезпечував теплопостачання будинків. Однак, ми пропонуємо, крім цього, утилізувати тепло редукторних мастил у допоміжному теплообміннику, що встановлений після випаровувача теплового насоса. Отримана додаткова теплова енергія використовується для випаровування хладагента R12 і охолодження редукторних мастил.

Практична значимість. ККД системи з теплонасосом досягає 4,08 без використання сонячних колекторів. Крім того, скорочується витрата палива. Таким чином, можна забезпечити економію енергії на 23,25 \% у порівнянні з традиційним водонагрівачем, що працюють на паливі.

Ключові слова: вітрова турбіна, теплонасос, температура редукторних мастил, водонагрівач, теплова енергія

\section{Технико-экономическое обоснование} использования редукторных масел ветровой
турбины для улучшения работы тепловых насосов в холодном климате

$$
\begin{aligned}
& \text { P. М.А. Эмак }{ }^{1,2}, \text { Э. Ху }{ }^{1,2}, \text { А. А. Алиаба }{ }^{3} \text {, } \\
& \text { А. А. М. Алсенви }{ }^{4}
\end{aligned}
$$

1 - Факультет машиностроения и электроинженерии, Китайский университет горного дела и технологий, г. Сюйчжоу, Китай, e-mail: hu@cumt.edu.cn

2 - Цзянсуский объединенный инновационный центр интеллектуального оборудования, Китайский университет горного дела и технологий, г. Сюйчжоу, Китай

3 - Инженерный колледж, Университет Минии, г. Минья, Египет

4 - Инженерный колледж, Арабская академия науки, технологии и морского транспорта, г. Александрия, Египет

Цель. Технико-экономическое обоснование (ТЭО) полного отказа от солнечных коллекторов (СК), используемых в системах с тепловыми насосами (ТН) для обеспечения теплоснабжения в холодных районах. 
Методика. Поскольку температура редукторных масел относительно высока, значительное количество тепла можно использовать. Утилизация неиспользованного тепла редукторных масел ветровой турбины становится перспективным решением проблемы повышения эффективности работы теплонасосов для теплоснабжения, особенно в холодном климате или в районах, которые расположены в северных широтах, где доля поступающей солнечной энергии невысока. Данное исследование касается ТЭО прямого преобразования механической энергии ветра в тепловую за счет трения внутри редуктора ветровой турбины с полным исключением использования солнечных коллекторов, которые применяются в комбинированных солнечных теплонасосах и имеют ряд недостатков - большие теплопотери, низкая эффективность, замерзание и прорыв труб - что сужает сферу их применения.

Результаты. Исследование показало, что ветровая турбина может обеспечить энергию, которая необходима для теплового насоса зимой (особенно в январе) благодаря высокой скорости ветра в округе Сюйчжоу, провинции Цзянсу, Китай. Даже без использования солнечных коллекторов коэффициент полезного действия (КПД) предлагаемой системы может достигать 4,08 при уменьшении потребления топлива на 23,25\%.

Научная новизна. В предыдущих исследованиях предлагалось использование ветровой турбины для приведения в действие теплонасоса, который надежно обеспечивал теплоснабжение домов. Однако, мы предлагаем, кроме этого, утилизировать тепло редукторных масел во вспомогательном теплообменнике, который установлен после испарителя теплонасоса. Полученная дополнительная тепловая энергия используется для испарения хладагента R12 и охлаждения редукторных масел.

Практическая значимость. КПД системы с теплонасосом достигает 4,08 без использования солнечных коллекторов. Кроме того, сокращается расход топлива. Таким образом, можно обеспечить экономию энергии на 23,25\% по сравнению с традиционным водонагревателем, работающим на топливе.

Ключевые слова: ветровая турбина, теплонасос, температура редукторных масел, водонагреватель, тепловая энергия

Recommended for publication by Prof. Gongbo Zhou. The manuscript was submitted 20.10.20. 